\title{
INVESTIGATION OF CLASS TEACHERS' OPINIONS ABOUT QUESTION ASKING SKILL, QUESTIONING STRATEGIES AND QUESTION TYPES
}

\author{
Coşkun Küçüktepe ${ }^{1 i}$, \\ Emre Çakmakci \\ ${ }^{1}$ Assoc. Prof., \\ Istanbul University-Cerrahpasa, \\ Istanbul, Turkey \\ orcid.org/0000-0003-3908-964X \\ ${ }^{2}$ Teacher, \\ Ministry of National Education, \\ Istanbul, Turkey \\ orcid.org/0000-0003-1632-8812
}

\begin{abstract}
:
In the current study, it was aimed to determine the opinions of primary school class teachers about their question asking skill, questioning strategies and the question types they use. The study employed the survey model, one of the qualitative research methods. In line with the purpose of the study, interviews were conducted with 52 primary school class teachers working in state and private schools in the Büyükçekmece district of the city of İstanbul. The data collected with a semi-structured interview form were analyzed by using the descriptive and content analysis methods. According to the results of the study, it was concluded that while determining the purposes of the questions they ask, the primary school class teachers mostly focus on evaluation, that the types of questions they use do not go beyond measuring the information possessed by students, that they think that the main advantage of asking questions is receiving feedbacks, that they think that knowing question asking strategies enables the teacher to improve the quality in education and that they think that the questions asked should be in compliance with the subjects and objectives. In light of these findings, it can be suggested that seminars and in-service training about question asking strategies should be given to teachers.
\end{abstract}

Keywords: class teacher, question asking skill, question types, questioning strategies

i Correspondence: email ckucuktepe@gmail.com 


\section{Introduction}

Given that asking question is an essential component of many teaching methods, it is clear that one of the most powerful tools a teacher uses in the learning and teaching process is questions. Aschner (1961) calls the teacher "a professional question maker" and states that asking questions is "one of the main ways that the teacher draws on to encourage students to think and learn".

Studies show that teachers ask many planned or spontaneous questions during teaching (Stevens, 1912; Gall, 1970; Wilen, 1987; Wragg, 1997). By asking questions, teachers serve many purposes such as testing student competencies in specific areas, encouraging students to think, engaging students in discussions in a non-threatening manner, developing respect and tolerance in students, and fostering cooperation and responsibility (Wilen, 1987). In addition, questions increase students' thinking ability, increase their curiosity, facilitate understanding, and enable them to establish connections between ideas (Büyükalan Filiz, 2002). Yet, the quality of questions is of great importance. Higher order questions, in other words, deep questions are the most important detail of critical thinking (Erdoğan, 2017). The questions that can be considered to be of high-quality lead students to critical logical, reflective, metacognitive and creative thinking (Mercan, 2018). Thus, it is clear that asking quality questions is important.

When the relevant literature is reviewed, it is seen that many studies have been conducted on questioning and asking questions (Bloom, 1956; Sanders, 1966; Barrett, 1968; Hunkins, 1972; Pearson and Johnson, 1978; Wilen, 1987; Wragg and Brown, 2001; Arslan, 2006; Küçüktepe 2010, Akyol et al., 2013; Küçüktepe 2015; Erdoğan, 2017; Yang, 2017; Cumhur, 2019). In addition to these, conducting studies to investigate teachers' awareness of the details of asking question and question types, the question asking approaches they have adopted and the underlying reasons is thought to be important.

In the current study, it was aimed to determine primary school class teachers' opinions about their question asking skill, questioning strategies and the types of questions they use. To this end, answers to the following questions were sought.

1) For which purpose or purposes do the class teachers ask questions to students while teaching in the class?

2) How many types of questions can a teacher ask students while teaching in the class?

3) What are the advantages or benefits provided by asking question for the teacher in the teaching process?

4) What are the advantages of knowing question asking strategies for a teacher?

5) What should teachers pay attention to while asking questions in the class? 


\section{Research Methodology}

\subsection{Method}

In the current study, the survey model, one of the qualitative research methods, was employed to determine primary school class teachers' opinions about their question asking skill, questioning strategies and the types of questions they use. Survey is a research model aiming to describe a present or past case as it is or was. The event, individual or object which is the subject of the research is attempted to be described as it is in its own conditions. There is no intervention to change them in any way. There is something to be known and it is there. What is important is to properly observe and document it (Karasar, 2018).

In the current study, interviews were conducted with a total of 52 class teachers working in state or private schools located in the Büyükçekmece district in the city of İstanbul. As the participants' opinions serving the purpose of the study are at the forefront, their demographic features are not mentioned. The current study is limited to the 2020-2021 school year and to the opinions of 52 teachers working in the Büyükçekmece district in the city of İstanbul.

\subsection{Data Collection Tools}

In the current study, a semi-structured interview form developed by the researcher was used to collect data. By seeking the opinions of two academicians about the items in the interview form, the reliability and validity of the form were increased.

\subsection{Data Analysis}

The responses given to the items in the semi-structured interview form were divided into themes and subjected to content analysis. Direct quotations from teacher responses are also given under the related themes. Moreover, frequencies and percentages were calculated on the basis of the frequency of the given responses. The collected data were descriptively analysed and then interpreted.

\section{Findings and Comments}

The data related to the purposes for which the primary school class teachers ask questions while teaching in the class are given in Table 1. As can be seen in Table 1, the main purpose for which the teachers ask questions is to evaluate students (28.5\%) while the purpose for which they use questions least was found to be to increase students' selfconfidence (6.1\%). Given that the purpose of asking questions is to encourage students to be engaged in higher order thinking, to internalize events and facts and accomplish better learning, it is seen that sufficient attention is not given to the purpose of making students think. 
Table 1: Classification of the Questions Asked by the Teachers While Teaching in the Class

\begin{tabular}{|l|c|c|l|}
\hline Purposes & $n$ & $f$ & \multicolumn{1}{|c|}{ Sample Quotations } \\
\hline Evaluating Students & 37 & $\mathbf{2 8 . 5 \%}$ & $\begin{array}{l}\text { I ask questions to evaluate the extent to } \\
\text { which they have achieved the objectives. } \\
\text { (TO19) }\end{array}$ \\
\hline Drawing Attention and Interest & 23 & $\mathbf{1 7 . 7 \%}$ & $\begin{array}{l}\text { I ask questions to draw their attention and } \\
\text { interest to lesson. (TO13) }\end{array}$ \\
\hline Testing Prior Knowledge & 18 & $\mathbf{1 3 . 8 \%}$ & $\begin{array}{l}\text { I ask questions to determine their level of } \\
\text { readiness. (TO7) }\end{array}$ \\
\hline Having Students Understand the Subject & 12 & $\mathbf{9 . 2 \%}$ & $\begin{array}{l}\text { I ask questions to test whether they have } \\
\text { understood the subject or not. (TO1) }\end{array}$ \\
\hline Having Students Think & 12 & $\mathbf{9 . 2} \%$ & $\begin{array}{l}\text { I ask questions to have my students establish } \\
\text { connections by thinking on the subject. } \\
\text { (TO23) }\end{array}$ \\
\hline Promoting Participation in Lesson & 11 & $\mathbf{8 . 5 \%}$ & $\begin{array}{l}\text { I ask questions to increase the participation } \\
\text { of children in lessons. (TO3) }\end{array}$ \\
\hline Keeping Students under Control & 9 & $\mathbf{7 \%}$ & $\begin{array}{l}\text { I ask questions to make sure that students are } \\
\text { listening to me. (TO27) }\end{array}$ \\
\hline Increasing Students' Self-Confidence & 8 & $\mathbf{6 . 1 \%}$ & $\begin{array}{l}\text { I ask questions to increase students' self- } \\
\text { confidence. (TO39) }\end{array}$ \\
\hline Total & 130 & $\mathbf{1 0 0 \%}$ & \\
\hline
\end{tabular}

The data related to the types of questions preferred by the primary school class teachers are presented in Table 2. As can be seen in Table 2, open-ended questions are frequently preferred with $23.8 \%$. Yet, the teachers more prefer to use Wh-questions to determine the existence of knowledge, multiple-choice questions, true-false questions, closed-ended questions and matching questions with $75.1 \%$. This might indicate that the questions preferred by the teachers only help students memorize.

Table 2: Type of questions preferred by the teachers

\begin{tabular}{|l|c|c|c|c|}
\hline Types of Questions & $n$ & $f$ & $n$ & $f$ \\
\hline Open-Ended Questions & 25 & $\mathbf{2 3 . 8 \%}$ & 25 & $\mathbf{2 3 . 8 \%}$ \\
\hline Wh-Questions & 20 & $\mathbf{1 9 \%}$ & 79 & $\mathbf{7 5 . 1 \%}$ \\
\cline { 1 - 3 } Fill-in Blank Questions & 16 & $\mathbf{1 5 . 2 \%}$ & & \\
\cline { 1 - 3 } Multiple-Type Questions & 16 & $\mathbf{1 5 . 2 \%}$ & & \\
\cline { 1 - 3 } True-False Questions & 10 & $\mathbf{9 . 5 \%}$ & & \\
\cline { 1 - 3 } Closed-Ended Questions & 10 & $\mathbf{9 . 5 \%}$ & & \\
\hline Matching Questions & 7 & $\mathbf{6 . 7 \%}$ & & $\mathbf{1 . 1 \%}$ \\
\hline Administrative Questions & 1 & $\mathbf{1 . 1 \%}$ & 1 & $\mathbf{1 0 0 \%}$ \\
\hline
\end{tabular}

As can be seen in Table 3, the primary school class teachers are of the opinion that the greatest advantage of asking question is to receive feedback (40\%). 


\begin{tabular}{|l|c|c|l|l|}
\hline \multicolumn{4}{|c}{ Table 3: Advantages provided by asking question for the teachers } \\
\hline Advantages & $n$ & $f$ & \multicolumn{1}{|c|}{ Sample Quotations } \\
\hline It Allows Receiving Feedback. & 38 & $\mathbf{4 0} \%$ & $\begin{array}{l}\text { By asking question, we test what } \\
\text { our students have learned. (TO23) }\end{array}$ \\
\hline It Increases Participation in Lesson. & 12 & $\mathbf{1 2 . 6 \%}$ & $\begin{array}{l}\text { Through questions, I encourage } \\
\text { students to participate in lesson. } \\
\text { (TO3) }\end{array}$ \\
\hline It Helps Attract Students' Attention and Interest. & 12 & $\mathbf{1 2 . 6 \%}$ & $\begin{array}{l}\text { I can draw attention and increase } \\
\text { curiosity. (TO16) }\end{array}$ \\
\hline It Helps Determine the Level of Students. & 10 & $\mathbf{1 0 . 5 \%}$ & $\begin{array}{l}\text { I can determine the levels and needs } \\
\text { of students. (TO36) }\end{array}$ \\
\hline It Makes Learning More Permanent. & 7 & $\mathbf{7 . 4 \%}$ & $\begin{array}{l}\text { It makes learning more permanent. } \\
\text { (TO32) }\end{array}$ \\
\hline It Enhances Teaching Process. & 6 & $\mathbf{6 . 3 \%}$ & $\begin{array}{l}\text { It facilitates and enhances teaching } \\
\text { process. (TO44) }\end{array}$ \\
\hline It Helps Control and Manage Students in the Class. & 4 & $\mathbf{4 . 2 \%}$ & $\begin{array}{l}\text { Through questions, I can have my } \\
\text { students listen to me more } \\
\text { attentively. (TO8) }\end{array}$ \\
\hline It Takes the Lesson out of Monotony. & & 3 & $\mathbf{3 . 2} \%$ & $\begin{array}{l}\text { Questions make the lesson more } \\
\text { active. (TO46) }\end{array}$ \\
\hline It Fosters Communication. & 3 & $\mathbf{3 . 2 \%}$ & $\begin{array}{l}\text { Questions ensure continuity in } \\
\text { communication. (TO40) }\end{array}$ \\
\hline Total & 95 & $\mathbf{1 0 0 \%}$ & \\
\hline
\end{tabular}

The effective use of question asking skill contributes to the development of teaching in many ways. According to the opinions stated by the participating teachers, its most important contribution is to improve the quality of education $(41.2 \%)$.

Table 4: Contributions of the effective use of question asking skill to teaching

\begin{tabular}{|l|c|c|l|}
\hline & $n$ & $f$ & \multicolumn{1}{|c|}{ Sample Quotations } \\
\hline Quality in Education & 28 & $\mathbf{4 1 . 2} \%$ & It increases the quality of education. (TO26) \\
\hline Competency in the Subject Area & 14 & $\mathbf{2 0 . 6} \%$ & $\begin{array}{l}\text { It helps the teacher see his/her level of competency. } \\
\text { (TO31) }\end{array}$ \\
\hline Efficiency in Education & 13 & $\mathbf{1 9 . 1 \%}$ & Appropriate techniques save time. (TO12) \\
\hline Classroom Management Skill & 9 & $\mathbf{1 3 . 2 \%}$ & It helps me manage the class well. (TO28) \\
\hline Job Satisfaction & 4 & $\mathbf{5 . 9} \%$ & $\begin{array}{l}\text { Effective teaching process increases the teacher's job } \\
\text { satisfaction. (TO40) }\end{array}$ \\
\hline Total & $\mathbf{6 8}$ & $\mathbf{1 0 0 \%}$ & \\
\hline
\end{tabular}

There are some certain points to be taken into consideration by teachers while using questions. These are elements that should be taken into account for questions to serve the purpose and to be effective. The participating teachers stated that the most important thing to be considered while asking questions is that questions should be in compliance with the subject and objectives (Table 5). The point which was found to be the least important in asking questions by the teachers is giving enough waiting time for students to answer. 
Table 5: Points to be taken into consideration while asking questions in the class

\begin{tabular}{|c|c|c|c|}
\hline & $n$ & $f$ & Sample Quotations \\
\hline $\begin{array}{l}\text { Their Being in Compliance } \\
\text { with the Subject and Objectives }\end{array}$ & 26 & $20.3 \%$ & $\begin{array}{l}\text { Attention should be paid to their suitability for } \\
\text { the lesson and subject. (TO4) }\end{array}$ \\
\hline $\begin{array}{l}\text { Their Being Suitable } \\
\text { for the Level of Students }\end{array}$ & 21 & $16.4 \%$ & $\begin{array}{l}\text { Attention should be paid for their suitability for } \\
\text { the level of students. (TO11) }\end{array}$ \\
\hline $\begin{array}{l}\text { Their Being Clear } \\
\text { and Comprehensible }\end{array}$ & 18 & $14.1 \%$ & $\begin{array}{l}\text { What the question is asking should be easily } \\
\text { understood. (TO15) }\end{array}$ \\
\hline $\begin{array}{l}\text { Their Being Attractive } \\
\text { and Interesting }\end{array}$ & 13 & $10.1 \%$ & $\begin{array}{l}\text { The questions to be asked should not distract } \\
\text { students' attention rather draw their attention. } \\
\text { (TO16) }\end{array}$ \\
\hline $\begin{array}{l}\text { Their Encouraging Students } \\
\text { to Research and Think } \\
\text { rather than to Memorize }\end{array}$ & 13 & $10.1 \%$ & $\begin{array}{l}\text { Care should be taken for questions to foster } \\
\text { thinking. (TO43) }\end{array}$ \\
\hline $\begin{array}{l}\text { Their not being Judgmental, } \\
\text { Offending, Insulting }\end{array}$ & 12 & $9.4 \%$ & $\begin{array}{l}\text { Questions should not put students into difficult } \\
\text { situations and they should not bore or upset } \\
\text { students in the class. (TO30) }\end{array}$ \\
\hline $\begin{array}{l}\text { Their Creating Opportunities } \\
\text { for Active Participation and Equality } \\
\text { in Answering for Students }\end{array}$ & 8 & $6.3 \%$ & $\begin{array}{l}\text { They should provide opportunities to answer } \\
\text { even for students who do not raise their fingers. } \\
\text { (TO13) }\end{array}$ \\
\hline $\begin{array}{l}\text { Their Being Directed } \\
\text { to Measuring Information }\end{array}$ & 5 & $3.9 \%$ & Wh-questions should be frequently used. (TO15) \\
\hline $\begin{array}{l}\text { Paying Attention to Tone } \\
\text { of Voice, Gestures and Mimics }\end{array}$ & 4 & $3.1 \%$ & $\begin{array}{l}\text { Questions should be asked by establishing an eye } \\
\text { contact. (TO50) }\end{array}$ \\
\hline Time of Asking Questions & 3 & $2.3 \%$ & $\begin{array}{l}\text { Questions should be asked at the correct time. } \\
\text { (TO26) }\end{array}$ \\
\hline $\begin{array}{l}\text { Having Other Students } \\
\text { Listen to the Respondent }\end{array}$ & 2 & $1.6 \%$ & The answer given should be listened to. (TO44) \\
\hline $\begin{array}{l}\text { They're not Being a } \\
\text { Tool to Assign Scores }\end{array}$ & 2 & $1.6 \%$ & $\begin{array}{l}\text { The teacher should not use questions to assign } \\
\text { scores. (TO5) }\end{array}$ \\
\hline $\begin{array}{l}\text { Attention Should } \\
\text { be Paid to Waiting Time }\end{array}$ & 1 & $0.8 \%$ & $\begin{array}{l}\text { Attention should be paid to waiting time for an } \\
\text { answer. (TO51) }\end{array}$ \\
\hline Total & 128 & $100 \%$ & \\
\hline
\end{tabular}

\section{Discussion and Results}

As a result of the analysis of the collected data, the following conclusions were reached: While determining the purposes for the questions they would ask, the primary school class teachers were found to focus on evaluating students and drawing students' attention and interest. In the study conducted by Kılıç and Erkuş (2015), it is stated that class teachers largely used questions for drawing attention and evaluation. This finding concurs with the result obtained in the current study. Moreover, Çalışkan (2011) argued that questions are important for students to accomplish the course objectives. However, given the effects of questions in the learning process, the frequent use of questions to evaluate students' accomplishment of objectives may result in the avoidance of other elements to be taken into consideration during educational and instructional activities. A great emphasis should be put on issues such as what kind of learning students have 
achieved during the process, the level of interest in the subject or lesson, participation in lesson, self-confidence, and maybe the more importantly, the thinking skills developed while seeking solutions to the questions asked.

In the study, the consistency of the themes with high scores in table 1, table 3 and table 5 is seen as an expected and remarkable situation. In this regard, the theme

"Evaluating Students" came to the fore among the purposes for which questions are asked by the teachers; the theme "Receiving Feedback" came to the fore among the advantages provided by asking questions for teachers and the theme "Their Being in Compliance with the Subject and Objectives" came to the fore among the points to be taken into consideration while asking questions in the class. The consistency found here can be explained as follows: The questions prepared for evaluation purposes are related to some certain objectives and target behaviours and at the same time give some feedback to the teacher on which objectives students have achieved or not.

Another finding of the current study is that with the question types they use, the teachers do not go beyond measuring only information in students. This is parallel to the findings in the literature. Küçüktepe (2010) investigated the types of questions used by primary school teachers in the teaching-learning process and found that the majority of the questions asked by the teachers had a single correct answer and thus, argued that the teachers could not make adequate contribution to the development of their students' thinking skills with the questions they asked. Akyol et al. (2013) also reported that teachers preferred to ask questions at the level of understanding. In the study conducted by Baysen (2006), it was found that teachers preferred questions at the information level. Ayvacı and Şahin (2009) also concluded that the questions asked in the class were largely at the information level, directing students to rote learning. Investigating the causes underlying teachers' avoidance of asking higher level questions, Sanders (1972) found that although teachers had been educated on the classification of questions, they were widely and consistently unsuccessful in using their questioning skills and that this is because not the teachers' rejecting the act of using various types of questions but rather, they found it difficult to use various types of questions. In the current study, the teachers were found to have no shortage of information about various types of questions. However, when the types of questions they preferred to use are considered, it can be argued that the reason why they less preferred to use questions requiring higher-order thinking was the difficulty of using these questions. This indicates the necessity of conducting research on how to systematize teachers' question asking practices.

The participating teachers were found to think that the greatest contribution of the effective use of question asking skill is to the quality of education. Improving quality of education is believed to make some important contributions to the professional development of teachers and their job satisfaction because when the quality of education is increased, teachers feel themselves obliged to professionally develop in their subject area and to be more competent and thus their job satisfaction increases as well. 


\title{
5. Suggestions
}

In light of the results of the current study, it can be suggested to organize seminars and in-service training programs to inform teachers about the basic principles of asking question, question asking and questioning strategies and effective use of various types of questions.

\section{Conflict of Interest Statement}

The authors declare no conflicts of interests.

\begin{abstract}
About the Authors
Coşkun Küçüktepe is working as an Associate Professor in the Department of Curriculum and Instruction in the Hasan Ali Yücel Education Faculty of İstanbul University-Cerrahpaşa.

Emre Çakmakcı is working as a class teacher in Büyükçekmece Atatürk Primary School in the Büyükçekmece district in the city of İstanbul. At the same time, he is a student at the Elementary Teaching Graduate Program of the Graduate Education Institute of İstanbul University-Cerrahpaşa.
\end{abstract}

\section{References}

Akyol, H., Yıldırım, K., Ateş, S. ve Çetinkaya, Ç. (2013). Anlamaya yönelik nasıl sorular soruyoruz?. Mersin Üniversitesi Ĕ̆itim Fakültesi Dergisi, 9(1), 41-56.

Aschner, M. J. (1961). Asking questions of trigger thinking. NEA Journals 50, 44-46

Aslan, M. (2006). The role of questioning in the classroom. Hasan Ali Yücel Ĕgitim Fakültesi Dergisi, 2, 81-103.

Ayvacı, H., Şahïn, Ç. (2009). Fen Bilgisi Öğretmenlerinin Ders Sürecinde ve Yazılı Sınavlarda Sordukları Soruların Bilişsel Seviyelerinin Karşılaştırılması. Uludağ Üniversitesi Eğitim Fakültesi Dergisi, 22 (2), 441-455.

Barrett, T. C. (1968). Taxonomy of cognitive and affective dimensions of reading comprehension. Akt. Clymer, T. in "What is reading?": some current concepts. Helen M. Robinson (Ed.). Innovation and change in reading instruction. Sixty-seventh yearbook: National Society for Study in Education, University of Chicago Press, 130.

Baysen, E. (2006). Öğretmenlerin sınıfta sordukları sorular ile öğrencilerin bu sorulara verdikleri cevapların düzeyleri. Kastamonu Eğitim Dergisi, 14(1), 21-28.

Bloom, B. S. (1956). Taxonomy of education objectives. The Classification of Educational Goals. Handbook I: Cognitive Domain. New York, NY: McKay.

Büyükalan Filiz, S. (2002). Soru-cevap yöntemine ilişkin öğretimin öğretmenlerin soru sorma düzeyi ve tekniklerine etkisi. (Yayımlanmamış yüksek lisans tezi). Gazi Üniversitesi, Eğitim Bilimleri Enstitüsü, Ankara. 
Cumhur, F. (2019). The Role of Questioning in Teaching: How to Develop Questioning Skills? Erzincan Üniversitesi Eğitim Fakültesi Dergisi. 25, (3), 32-55.

Çalışkan, H. (2011). Öğretmenlerin hazırladığı sosyal bilgiler dersi sınav sorularının değerlendirilmesi. Eğitim ve Bilim, 36(160), 120-132.

Erdoğan, T. (2017). İlkokul Dördüncü Sınıf Öğrencilerinin ve Öğretmenlerinin Türkçe Dersine İlişkin Sordukları Soruların Yenilenmiş Bloom Taksonomisi Açısından Görünümü. Eğitim ve Bilim 2017, 42, (192), 173-191

Gall, M. (1970). The use of questions in teaching. Review of Educational Research. 40 (5), 707-721.

Hunkins, F. P. (1972). Questioning Strategies and Techniques. Boston: Allyn and Bacon, Inc.

Karasar, N. (2018). Bilimsel Araştırma Yöntemi: kavramlar, ilkeler, teknikler. Ankara: Nobel Yayıncilik.

Kılıç, D. ve Erkuş, B. (2015). Sınıf öğretmenlerinin soru sorma stratejileri ve karşılaştıkları sorunlar. Manas Sosyal Araştırmalar Dergisi. 4 (5). s 230-243

Küçüktepe, C. (2010). Examination of question types used by elementary school teachers in the process of teaching and learning. Procedia Social and Behavioral Sciences, 2, 5190-5195.

Küçüktepe, C. (2015). An Evaluation of Teachers' Questions in Terms of Socratic Inquiry Technique. Anthropologist, 20(1,2): 156-165.

Mercan, F. Ç. (2018). Üst Düzey Düşünme Becerileri. Retrieved: 10.02.2021 http://web.boun.edu.tr/fatih.mercan/udb2018/\#: :text=Tan\%C4\%B1m,ikilemlerle \%20kar\%C5\%9F\%C4\%B1la\%C5\%9Ft\%C4\%B1klar\%C4\%B1nda\%20aktif\%20hale $\% 20$ gelirler.

Pearson, P. D. ve Johnson, D. D. (1978). Teaching reading comprehension. New York: Holt Rinehart and Winston.

Sanders, N. M. (1966). Classroom questions: What kinds? New York, N.Y.: Harper \& Row.

Sanders, N. M. (1972) A second look at classroom questions. The High School Journal. 55 (6) s. $265-277$.

Stevens, R. (1912). The Question of Measure of Efficently in Instruction. New York: Teacher College, Colombia University Press.

Yang, H. (2017). A Research on the Effective Questioning Strategies in Class. Science Journal of Education. 5, (4), 158-163. doi: 10.11648/j.sjedu.20170504.16.

Wilen, W. W. (1987). Questions, Questioning Techniques, and Effective Teaching. Washington: National Education Association of the United States.

Wragg, E. C. (1997). Cubic Curriculum. London: Routledge.

Wragg, E. C. ve Brown, G. (2001). Questioning in the primary school. New York: Routledge Falmer. 
Author(s) will retain the copyright of their published articles agreeing that a Creative Commons Attribution 4.0 International License (CC BY 4.0) terms will be applied to their work. Under the terms of this license, no permission is required from the author(s) or publisher for members of the community to copy, distribute, transmit or adapt the article content, providing a proper, prominent and unambiguous attribution to the authors in a manner that makes clear that the materials are being reused under permission of a Creative Commons License. Views, opinions and conclusions expressed in this research article are views, opinions and conclusions of the author(s). Open Access Publishing Group and European Journal of Education Studies shall not be responsible or answerable for any loss, damage or liability caused in relation to/arising out of conflicts of interest, copyright violations and inappropriate or inaccurate use of any kind content related or integrated into the research work. All the published works are meeting the Open Access Publishing requirements and can be freely accessed, shared, modified, distributed and used in educational, commercial and non-commercial purposes under a Creative Commons Attribution 4.0 International License (CC BY 4.0). 